\title{
The effect of coriander seed (Coriandrum sativum L.) as diet ingredient on the performance of Japanese quail
}

\author{
T. Güler ${ }^{1 \#}$, O.N. Ertaş ${ }^{1}$, M. Çiftçi ${ }^{1}$ and B. Dalkılıç ${ }^{1}$ \\ ${ }^{1}$ Department of Animal Nutrition, Veterinary Faculty, University of Firat, 23119 Elazığ-Turkey
}

\begin{abstract}
This study was conducted to determine the potential of coriander seed as a natural growth promoting substance in quail nutrition. Five hundred and ninety four 3-day old Japanese quails were divided into six groups of 99 birds each and randomly assigned to six treatment diets. Four of the diets contained coriander seed at $0.5 \%, 1 \%, 2 \%$ or $4 \%$ levels of inclusion, one contained $10 \mathrm{mg}$ of the antibiotic, avilamycin, per $\mathrm{kg}$ and a control group received no supplement. Effects on feed intake, daily live weight gain, feed conversion ratio and carcass characteristics of the birds were measured over a period of 42 days. After 42 days the highest feed intake was observed in the $4 \%$ coriander group. Birds receiving the diet containing $2 \%$ coriander seed showed the highest weight gain, followed by those receiving the diets containing $1 \%$ coriander seed, the antibiotic, the $4 \%$ and the $0.5 \%$ coriander seed. The control had the lowest weight gain. The feed conversion ratio over the experimental period was significantly better in the group receiving $2 \%$ coriander seed than in the other treatments. The highest carcass yield and liver weights were also recorded in the $2 \%$ coriander group, while the lowest abdominal fat percentages were present in the $1 \%, 2 \%$ and $4 \%$ coriander groups. These results suggested that coriander seeds could be considered a potential natural growth promoter for poultry, and showed the best responses at a $2 \%$ level of inclusion.
\end{abstract}

Keywords: Coriander seed, antibiotics, performance, Japanese quail

\#Corresponding author. E-mail: tguler@firat.edu.tr, talatguler@yahoo.com

\section{Introduction}

Dietary antibiotics have played an important role in animal production as growth and health promoters. However, the use of most antibiotic growth promoters has been banned in many countries, especially in the European Union, because of public concerns about their residues in the animal products and the development of antibiotics-resistant bacteria (Schwarz et al., 2001; Lee et al., 2004). Consequently, the use of antibiotics in poultry diets has been curtailed and scientists have been searching for alternatives to antibiotics. In view of this, aromatic plants and essential oils extracted from these plants have become more important due to their potential antimicrobial and stimulating effects in the animal digestive system. Aromatic plants have been used traditionally as antiparasitic, anthelmintic, analgesic, expectorant, sedative, antiseptic and antidiabetic substances in many parts of the world (Lee et al., 2004). In addition, they possess antimicrobial activity, (Elgayyar et al., 2001; Singh et al., 2002; Valero \& Salmeron, 2003), biological activities such as that of antioxidants (Chithara \& Leelamma, 1999; Miura et al., 2002) and hypocholesterolemics (Craig, 1999). Recent studies have shown that they have a stimulating effect on the digestive systems of animals, through the increasing production of digestive enzymes and by improving the utilization of digestive products through enhanced liver function (Langhout, 2000; Williams \& Losa, 2001; Hernandez et al., 2004). Furthermore, limited research has suggested that some aromatic plants and their components could improve feed intake, feed conversion ratio and carcass yield (Ather, 2000; Bassett, 2000; Hertrampt, 2001; Tucker, 2002).

As an aromatic plant, coriander (Coriandrum sativum L.) is an annual species of the parsley family, native to the eastern Mediterranean region and southern Europe, and is found in many other parts of the world. Coriander seed is used primarily as a flavouring agent in the food industry or as a spice in bread, cheese, curry, fish, meat, sauces, soup, pastries and confections. They are used as a flavouring agent in bread and yield essential oil for the manufacturing of soaps and perfumes. Coriander has been used as a medicine for thousands of years and is still used in folk medicine. As a medicinal plant, coriander has been used to manage diabetes (Swantson-Flatt, 1990; Gray, 1999), used as an anti-fungal (Basilico \& Basilico, 1999), antioxidant (Chithara \& Leelamma, 1999), hypolipidemic (Chithara \& Leelamma, 2000), antimicrobial 
(Delaquis et al., 2002; Singh et al., 2002; Elgayyar et al., 2001), hypocholesterolemic (Chithara \& Leelamma, 1997) and anticonvulsant (Hossein \& Mohammed, 2000) substance. In addition, it has appetizing and stimulatory effects in the digestion process (Çabuk et al., 2003). However, no reports are available on the effect of coriander on animal performance.

In this study, we investigated the use of coriander seed compared to an antibiotic in animal nutrition as a natural growth promoting substance. For this purpose, the effects of different inclusion levels of coriander seeds were assessed.

\section{Materials and Methods}

Five hundred and ninety four 3-day old Japanese quail chicks were divided into six treatments of 99 birds each and randomly assigned to six treatment groups. The presence and levels of coriander seed and antibiotics in diets were the main factors tested. In the control group, the birds were fed a standard diet (240 g CP and 12.12 MJ ME/kg, according to NRC (1994). Four different levels of coriander seed and one level of an antibiotic were added to the standard diets to generate another five treatment groups. For the coriander treatments, $0.5 \%$ ( $0.5 \%$ coriander group), $1 \%$ ( $1 \%$ coriander group), $2 \%$ ( $2 \%$ coriander group) and $4 \%$ ( $4 \%$ coriander group) of coriander seed were added to the standard diets. In the antibiotic treatment, the feed contained $10 \mathrm{mg} / \mathrm{kg}$ of an antibiotic, avilamycin (Kartal Kimya,Turkey). Coriander seeds were ground in a mill, using a $2.5 \mathrm{~mm}$ sieve. The diets were prepared to be isoenergetic and isonitrogenous. Diets and water were provided ad libitum. The ingredient and chemical composition of the diets are presented in Table 1.

Table 1 Dietary ingredients and chemical composition of the experimental diets (as fed)

\begin{tabular}{|c|c|c|c|c|c|c|}
\hline & \multirow{2}{*}{ Control } & \multicolumn{4}{|c|}{ Coriander seed ( $\%$ in diet $)$} & \multirow{2}{*}{ Antibiotic } \\
\hline & & 0.5 & 1 & 2 & 4 & \\
\hline \multicolumn{7}{|l|}{ Ingredients $(\mathrm{kg} / 1000 \mathrm{~kg})$} \\
\hline Maize & 570.7 & 566.7 & 562.7 & 554.6 & 538.5 & 570.7 \\
\hline Sunflower seed meal & 18.6 & 17.3 & 16.1 & 13.6 & 8.7 & 18.6 \\
\hline Soyabean meal (45 CP) & 350.0 & 350.0 & 350.0 & 350.0 & 350.0 & 350.0 \\
\hline Fish meal & 38.9 & 39.2 & 39.5 & 40.0 & 41.1 & 38.9 \\
\hline Salt & 2.8 & 2.8 & 2.8 & 2.7 & 2.7 & 2.8 \\
\hline DL-Methionine & 0.8 & 0.8 & 0.9 & 0.9 & 0.9 & 0.8 \\
\hline Vitamin premix* & 1.2 & 1.2 & 1.2 & 1.2 & 1.2 & 1.2 \\
\hline Mineral premix $* *$ & 1.2 & 1.2 & 1.2 & 1.2 & 1.2 & 1.2 \\
\hline Dicalcium phosphate & 6.9 & 6.9 & 6.9 & 6.9 & 6.8 & 6.9 \\
\hline Ground limestone & 8.9 & 8.8 & 8.8 & 8.8 & 8.8 & 8.9 \\
\hline Coriander seeds & 0 & 5.0 & 10.0 & 20.0 & 40.0 & 0 \\
\hline Antibiotic (avilamycin) & - & - & - & - & - & 0.01 \\
\hline Total & 1000 & 1000 & 1000 & 1000 & 1000 & 1000 \\
\hline \multicolumn{7}{|l|}{ Chemical analysis (g/kg DM) } \\
\hline Dry matter & 882.3 & 882.6 & 882.9 & 883.5 & 884.7 & 882.3 \\
\hline Crude protein $(\mathrm{CP})$ & 240.0 & 240.0 & 240.0 & 240.0 & 240.0 & 240.0 \\
\hline Crude fibre & 39.6 & 40.7 & 41.8 & 44.1 & 48.7 & 39.6 \\
\hline Ash & 58.2 & 58.4 & 58.6 & 59.0 & 59.7 & 58.2 \\
\hline Ether extract & 28.4 & 29.1 & 29.8 & 31.2 & 34.0 & 28.4 \\
\hline \multicolumn{7}{|c|}{ Estimated chemical analysis $(\mathrm{g} / \mathrm{kg})$} \\
\hline Calcium & 8.0 & 8.0 & 8.0 & 8.0 & 8.0 & 8.0 \\
\hline Phosphorus & 4.0 & 4.0 & 4.0 & 4.0 & 4.0 & 4.0 \\
\hline Methionine & 5.0 & 5.0 & 5.0 & 5.0 & 5.0 & 5.0 \\
\hline Lysine & 13.6 & 13.6 & 13.6 & 13.6 & 13.6 & 13.6 \\
\hline Linoleic acid & 12.7 & 12.7 & 12.7 & 12.7 & 12.7 & 12.7 \\
\hline $\mathrm{ME}, \mathrm{MJ} / \mathrm{kg}$ & 12.12 & 12.12 & 12.12 & 12.12 & 12.12 & 12.12 \\
\hline
\end{tabular}

ME - Metabolisable energy

* Vitamin premix (/kg diet): Vitamin A - $1.000 \mathrm{IU}$; vitamin $\mathrm{D}_{3}-1.000 \mathrm{IU}$; vitamin $\mathrm{E}-42 \mathrm{~g}$; vitamin $\mathrm{K}_{3}-4 \mathrm{~g}$; vitamin $\mathrm{B}_{1}-3.6 \mathrm{mg}$; vitamin $\mathrm{B}_{2}-7 \mathrm{~g}$; vitamin $\mathrm{B}_{6}-8 \mathrm{mg}$; vitamin $\mathrm{B}_{12}-0.02 \mathrm{mg}$; niasin - $24 \mathrm{mg}$; folic acid - $12 \mathrm{mg}$; biotin - $0.05 \mathrm{mg}$; cal-D-pentotenat (pantothenic acid) - $12 \mathrm{mg}$; cholin chloride - $150 \mathrm{mg}$; vitamin $\mathrm{C}-60 \mathrm{mg}$

** Mineral premix (mg/kg diet): $\mathrm{Fe}-72 ; \mathrm{Zn}-72 ; \mathrm{Cu}-6 ; \mathrm{I}-1.2 ; \mathrm{Co}-0.24 ; \mathrm{Se}-0.18 ; \mathrm{Mn}-96$ 
For the experimental period of 42 days the quails were kept in cages $(19 \times 20 \times 22 \mathrm{~cm})$, three quails per cage. Photoperiods were maintained at $23 \mathrm{~h} / \mathrm{d}$ for the first four weeks and at $14 \mathrm{~h} / \mathrm{d}$ for weeks 5 and 6 . The body weights of the birds were measured individually and per cage. Feed intake was recorded per cage. Feed conversion ratio was calculated after 42 days. Mortalities were recorded daily. At 42 days, 20 birds of similar body weights were selected from each treatment group, weighed and killed by $\mathrm{CO}_{2}$ asphyxiation. The feathers were removed and internal organs were collected. Weights of the fresh hearts and livers were measured. The carcasses were kept at $+4{ }^{\circ} \mathrm{C}$ for $24 \mathrm{~h}$ whereafter cold carcass and abdominal fat weights were measured.

The dry matter, crude protein, ash and ether extract content of the diets were analysed using AOAC (1990) procedures, and crude fibre was determined, using the Crampton \& Maynard (1983) method. Collected data were subjected to analysis of variance, and means were further subjected to Duncan's multiple range tests using SPSS for Windows (10.1) (SPSS, 1999) where significant differences were observed. The results were considered as significant when $\mathrm{P}$ values were $<0.05$ and $<0.01$.

\section{Results and Discussion}

The effects of different dietary levels of coriander seed or an antibiotic on feed intake are presented in Table 2. For the first four weeks feed intakes were similar in all groups $(\mathrm{P}>0.05)$. However, during weeks 5 and 6, and over the entire experimental period of six weeks feed intakes differed significantly $(\mathrm{P}<0.05)$ between treatments. During the six week period there were no differences $(\mathrm{P}>0.05)$ in feed intake between the individual coriander groups or the antibiotic group, but higher $(\mathrm{P}<0.05)$ than that of the control group, except for the $0.5 \%$ coriander group where the intake did not differ $(\mathrm{P}>0.05)$ from that of the control. The improvement in the feed intake with the addition of coriander seed could be due to essential oils and their main component, linalool, in coriander seeds. It has been reported that linalool has an appetizing effect in diets and stimulates the digestive process in animals (Çabuk et al., 2003). Positive effects of essential oils on feed intake have also been reported previously (Ather, 2000; Hertrampf, 2001; Williams \& Losa, 2001).

Table 2 The effect of different levels of coriander seed and an antibiotic (10 mg avilamycin $/ \mathrm{kg}$ ) in their diets on the average daily feed intake of growing quails $(\mathrm{g} / \mathrm{bird} / \mathrm{day})(\mathrm{n}=33)$

\begin{tabular}{|c|c|c|c|c|c|c|c|}
\hline \multirow{2}{*}{ Week } & \multirow{2}{*}{ Control } & \multicolumn{4}{|c|}{ Coriander seed ( $\%$ in diet) } & \multirow{2}{*}{ Antibiotic } & \multirow{2}{*}{ s.e.m. } \\
\hline & & 0.5 & 1 & 2 & 4 & & \\
\hline 1 & 9.13 & 8.70 & 8.93 & 8.77 & 9.16 & 9.26 & 1.90 \\
\hline 2 & 13.24 & 13.37 & 13.11 & 13.08 & 14.44 & 13.36 & 2.08 \\
\hline 3 & 16.97 & 16.74 & 16.12 & 16.30 & 16.60 & 16.09 & 2.24 \\
\hline 4 & 22.68 & 22.47 & 23.11 & 23.25 & 22.66 & 23.00 & 2.00 \\
\hline 5 & $21.07^{\mathrm{b}}$ & $23.99^{\mathrm{a}}$ & $23.19^{\mathrm{ab}}$ & $24.11^{\mathrm{a}}$ & $23.80^{\mathrm{a}}$ & $23.40^{\mathrm{a}}$ & 0.45 \\
\hline 6 & $21.99^{b}$ & $22.91^{\mathrm{ab}}$ & $24.26^{\mathrm{a}}$ & $23.67^{\mathrm{a}}$ & $23.70^{\mathrm{a}}$ & $24.05^{\mathrm{a}}$ & 0.72 \\
\hline $1-6$ & $17.51^{\mathrm{b}}$ & $17.99^{\mathrm{ab}}$ & $18.12^{\mathrm{a}}$ & $18.19^{\mathrm{a}}$ & $18.39^{\mathrm{a}}$ & $18.19^{\mathrm{a}}$ & 0.98 \\
\hline
\end{tabular}

${ }^{\bar{a} . b}$ Means within rows with different superscripts differ significantly $(\mathrm{P}<0.05)$; s.e.m. - standard error of mean

The effect of including coriander seeds or the antibiotic in the diet on the daily live weight gain of the quails is presented in Table 3. From weeks 1 to 6 daily body weights differed $(\mathrm{P}<0.05)$ between treatments. The birds consuming the diet containing $2 \%$ coriander seed showed a higher daily weight gain on average than those on the other experimental diets. There were no differences $(\mathrm{P}>0.05)$ in average daily weight gain of the birds receiving the diets containing $1 \%$ and $4 \%$ coriander seeds and the antibiotic. Furthermore, there were no differences $(\mathrm{P}>0.05)$ between daily weight gains of birds receiving the diets containing $0.5 \%$ coriander seed and the control diet. The average daily gains of the birds receiving the diets containing $0.5 \%$, $1 \%$ and $4 \%$ coriander seed were lower $(\mathrm{P}<0.05)$ than those on the diet containing $2 \%$ coriander seed. The inclusion of $2 \%$ coriander seed to the diets improved daily live weight gain by $8.3 \%$ compared to the control group. This improvement above the control was $5.4 \%$ for $1 \%$ coriander and antibiotic groups and $3.6 \%$ for 
the $4 \%$ coriander group. The addition of $2 \%$ coriander seed to the diet improved live weight gain by $2.7 \%$ above that of the antibiotic group.

Table 3 The effect of different levels of coriander seed and an antibiotic (10 mg avilamycin $/ \mathrm{kg}$ ) in their diets on the average daily live weight gain of growing quails ( $g /$ bird/day) $(n=99)$

\begin{tabular}{|c|c|c|c|c|c|c|c|}
\hline \multirow{2}{*}{ Week } & \multirow{2}{*}{ Control } & \multicolumn{4}{|c|}{ Coriander seed ( $\%$ in diet) } & \multirow{2}{*}{ Antibiotic } & \multirow{2}{*}{ s.e.m } \\
\hline & & 0.5 & 1 & 2 & 4 & & \\
\hline 1 & $3.86^{\mathrm{ab}}$ & $3.77^{\mathrm{b}}$ & $3.97^{\mathrm{a}}$ & $3.89^{\mathrm{ab}}$ & $3.96^{\mathrm{a}}$ & $3.95^{\mathrm{a}}$ & 1.74 \\
\hline 2 & $5.32^{\mathrm{ab}}$ & $5.27^{\mathrm{ab}}$ & $5.37^{\mathrm{a}}$ & $5.20^{\mathrm{b}}$ & $5.48^{\mathrm{a}}$ & $5.44^{\mathrm{a}}$ & 2.18 \\
\hline 3 & $5.87^{\mathrm{c}}$ & $5.66^{\mathrm{c}}$ & $5.97^{\mathrm{bc}}$ & $6.01^{\mathrm{b}}$ & $6.38^{\mathrm{a}}$ & $6.08^{\mathrm{b}}$ & 2.04 \\
\hline 4 & $4.08^{\mathrm{c}}$ & $4.64^{\mathrm{b}}$ & $4.69^{\mathrm{b}}$ & $5.37^{\mathrm{a}}$ & $4.13^{\mathrm{c}}$ & $4.53^{\mathrm{b}}$ & 1.98 \\
\hline 5 & $2.60^{\mathrm{c}}$ & $3.05^{\mathrm{b}}$ & $3.01^{\mathrm{b}}$ & $3.31^{\mathrm{a}}$ & $2.96^{\mathrm{b}}$ & $2.92^{\mathrm{b}}$ & 1.86 \\
\hline 6 & $1.43^{\mathrm{a}}$ & $1.04^{\mathrm{b}}$ & $1.43^{\mathrm{a}}$ & $1.30^{\mathrm{c}}$ & $1.07^{\mathrm{b}}$ & $1.50^{\mathrm{a}}$ & 2.45 \\
\hline $1-6$ & $3.86^{\mathrm{c}}$ & $3.91^{\mathrm{c}}$ & $4.07^{\mathrm{b}}$ & $4.18^{\mathrm{a}}$ & $4.00^{\mathrm{bc}}$ & $4.07^{\mathrm{b}}$ & 2.00 \\
\hline
\end{tabular}

$\overline{{ }^{a . b . c}}$ Means within rows with different superscripts differ significantly $(\mathrm{P}<0.05)$; s.e.m. - standard error of mean

From weeks 1 to 6 , feed conversion ratios were significantly improved by the supplementation of coriander seed at levels of $1 \%$ and $2 \%$ inclusion, and in the antibiotic group compared to those birds on the diets containing $0.5 \%$ and $4 \%$ coriander seed and the control $(\mathrm{P}<0.05)$. The lowest feed conversion ratio occurred in the $2 \%$ coriander group. The inclusion of $2 \%$ coriander seed in the diet improved the feed conversion ratio by $4.3 \%$ over the control group and by $c a .3 \%$ over the antibiotic and $1 \%$ coriander groups. The inclusion of $1 \%$ coriander seed and the antibiotic in the diet improved the feed conversion ratio by $c a$. $2 \%$ compared to the control diet. However, the feed conversion ratios were similar for the entire experimental period of six weeks for the birds receiving the control diet and the diets containing $0.5 \%$ and $4 \%$ coriander seed.

Table 4 The effect of different levels of coriander seed and an antibiotic (10 mg avilamycin $/ \mathrm{kg}$ ) in their diets on the feed conversion ratio ( $\mathrm{g}$ feed/g gain) of growing quails $(\mathrm{n}=33)$

\begin{tabular}{|c|c|c|c|c|c|c|c|}
\hline \multirow{2}{*}{ Week } & \multirow{2}{*}{ Control } & \multicolumn{4}{|c|}{ Coriander seed ( $\%$ in diet) } & \multirow[b]{2}{*}{ Antibiotics } & \multirow[b]{2}{*}{ s.e.m } \\
\hline & & 0.5 & 1 & 2 & 4 & & \\
\hline 1 & $2.37^{\mathrm{a}}$ & $2.31^{\mathrm{b}}$ & $2.25^{\mathrm{c}}$ & $2.25^{\mathrm{c}}$ & $2.31^{\mathrm{b}}$ & $2.34^{\mathrm{a}}$ & 0.32 \\
\hline 2 & $2.49^{\mathrm{bc}}$ & $2.54^{\mathrm{b}}$ & $2.44^{\mathrm{c}}$ & $2.52^{\mathrm{b}}$ & $2.64^{\mathrm{a}}$ & $2.46^{\mathrm{c}}$ & 0.75 \\
\hline 3 & $2.89^{\mathrm{a}}$ & $2.96^{\mathrm{a}}$ & $2.70^{\mathrm{b}}$ & $2.71^{\mathrm{b}}$ & $2.60^{\mathrm{c}}$ & $2.65^{\mathrm{bc}}$ & 0.78 \\
\hline 4 & $5.56^{\mathrm{a}}$ & $4.84^{\mathrm{bc}}$ & $4.93^{\mathrm{bc}}$ & $4.33^{\mathrm{c}}$ & $5.49^{\mathrm{a}}$ & $5.08^{\mathrm{b}}$ & 0.24 \\
\hline 5 & $8.10^{\mathrm{a}}$ & $7.87^{\mathrm{bc}}$ & $7.70^{\mathrm{bc}}$ & $7.28^{\mathrm{c}}$ & $8.04^{\mathrm{a}}$ & $8.01^{\mathrm{a}}$ & 0.45 \\
\hline 6 & $15.38^{\mathrm{c}}$ & $22.03^{\mathrm{a}}$ & $16.97^{\mathrm{c}}$ & $18.21^{\mathrm{b}}$ & $22.15^{\mathrm{a}}$ & $16.03^{\mathrm{c}}$ & 1.24 \\
\hline $1-6$ & $4.54^{\mathrm{a}}$ & $4.60^{\mathrm{a}}$ & $4.45^{\mathrm{b}}$ & $4.35^{\mathrm{c}}$ & $4.60^{\mathrm{a}}$ & $4.47^{\mathrm{b}}$ & 0.32 \\
\hline
\end{tabular}

$\overline{{ }^{a . b . c}}$ Means within rows with different superscripts differ significantly $(\mathrm{P}<0.05)$; s.e.m. - standard error of mean

After six weeks carcass weights differed $(\mathrm{P}<0.05)$ between the treatments. The birds consuming the diet containing $2 \%$ coriander seed $(137.5 \mathrm{~g})$ had the highest cold carcass weight, followed by the birds on the diets containing 1\% coriander seed (132.6 g), $10 \mathrm{mg}$ antibiotic/kg (132.4 g), 4\% coriander seed (130.2 g), $0.5 \%$ coriander seed $(125.9 \mathrm{~g})$ and the control diet $(122.8 \mathrm{~g})$. The addition of $2 \%$ coriander seed to the diet improved cold carcass weight by $11.97 \%$ compared to the control group. Significant differences were also found between the $2 \%$ coriander group and the other treatment groups. Similarly, the highest liver weights were recorded in the $2 \%$ group $(\mathrm{P}<0.05)$ while heart weights were similar in all groups $(\mathrm{P}>0.05)$. 
Abdominal fat percentage was the highest in the control, the $0.5 \%$ coriander and antibiotic groups, followed by the $1 \%$ coriander, $4 \%$ coriander and $2 \%$ coriander groups $(\mathrm{P}<0.05)$. The reason for the low abdominal fat content in the $1 \%, 2 \%$ and $4 \%$ coriander groups could be due to a hypolipidemic effect observed in diets containing coriander seed (Chithra \& Leelamma, 1997; 2000).

Table 4 The effect of different levels of coriander seed and an antibiotic (10 mg Avilamycin $/ \mathrm{kg}$ ) in the diets of quails on their carcass characteristics $(n=20)$

\begin{tabular}{|c|c|c|c|c|c|c|c|}
\hline & \multirow{2}{*}{ Control } & \multicolumn{4}{|c|}{ Coriander seed ( $\%$ in diet $)$} & \multirow{2}{*}{ Antibiotic } & \multirow{2}{*}{ s.e.m. } \\
\hline & & 0.5 & 1 & 2 & 4 & & \\
\hline Live weight, $\mathrm{g}$ & $178.0^{\mathrm{b}}$ & $179.9^{b}$ & $186.8^{\mathrm{ab}}$ & $190.0^{\mathrm{a}}$ & $183.4^{\mathrm{ab}}$ & $186.4^{\mathrm{ab}}$ & 3.27 \\
\hline Cold carcass, $g$ & $122.8^{\mathrm{c}}$ & $125.9^{\mathrm{c}}$ & $132.6^{\mathrm{b}}$ & $137.5^{\mathrm{a}}$ & $130.2^{b}$ & $132.4^{\mathrm{b}}$ & 2.12 \\
\hline Carcass yield/live weight, $\%$ & $69.0^{\mathrm{b}}$ & $70.0^{\mathrm{b}}$ & $70.1^{\mathrm{b}}$ & $72.4^{\mathrm{a}}$ & $70.1^{\mathrm{b}}$ & $71.0^{\mathrm{ab}}$ & 1.35 \\
\hline Heart weight, $\%$ of live weight & 0.76 & 0.78 & 0.77 & 0.80 & 0.77 & 0.78 & 1.45 \\
\hline Liver weight, $\%$ of live weight & $1.69^{\mathrm{b}}$ & $1.79^{\mathrm{ab}}$ & $1.84^{\mathrm{ab}}$ & $2.04^{\mathrm{a}}$ & $1.81^{\mathrm{ab}}$ & $1.83^{\mathrm{ab}}$ & 1.35 \\
\hline Abdominal fat, $\%$ of cold carcass weight & $1.25^{\mathrm{a}}$ & $1.19^{\mathrm{ab}}$ & $1.09^{b}$ & $1.03^{b}$ & $1.08^{b}$ & $1.16^{\mathrm{ab}}$ & 0.95 \\
\hline
\end{tabular}

${ }^{\text {a.b.c }}$ Means within rows with different superscripts differ significantly $(\mathrm{P}<0.05)$; s.e.m. - standard error of mean

The supplementation of $2 \%$ coriander seeds significantly improved daily live weight gain, feed conversion ratio and carcass yield. These positive improvements could be due to the essential oils present in coriander seed. Coriander seed contains essential oils (up to $1 \%$ ) such as linalool $(60-70 \%)$ and other monoterpenoids such as citronellol, geraniol, myrcene, $\alpha$ - and $\gamma$-terpinene, limonene, $\alpha$ - and $\beta$-phellandrene, $p$-cymene, $\alpha$ - and $\beta$-pinene and camphor (Wichtl, 1994). According to Çabuk et al. (2003) linalool has appetizing properties in a diet and stimulating effects on the digestive process. It furthermore inhibits pathogenic microorganisms in the digestive system. Delaquis et al. (2002) reported that essential oils derived from coriander seeds negatively affected gram-positive bacteria, gram-negative bacteria and Saccharomyces cerevisiae. Similarly, Çabuk et al. (2003) reported that linalool affected Escherichia coli, Pseudomonas aeruginosa, Salmonella typhimurium, Staphylococcus aureus, Clostridium botulinum and Clostridium perfingers negatively. It is clear that controlling the gut micro flora can positively influence the performance of birds. The improved feed utilization with $2 \%$ coriander seed in the present study could be due to the stimulating effect of these essential oils on the digestive process. In agreement with these results, Hernandez et al. (2004) reported that the supplementation of essential oils improved apparent whole tract and ileal digestibility of nutrients. Similarly, Ramakrishna et al. (2003) reported that the effectiveness of pancreatic lipase and amylase was increased through the supplementation of essential oils. Similar positive effects were reported by Jamroz \& Kamel (2002). They observed that the supplementation of essential oils increased the digestion of protein, cellulose and fat in pigs. The positive effect of dietary coriander seed on body weight gain and the feed conversion ratio could be related to the increased efficiency of feed utilization and/or altered carcass composition. Similarly, Ather (2000) reported an improved performance in broilers when a poly-herbal premix which contained five herbs was used. In agreement with these results, similar results were observed in recent studies where it was reported that essential oils had blocking effects on pathogens in the digestive system (Alçiçek et al., 2003), and improved feed intakes, feed conversion ratios and carcass yields (Basset, 2000; Hertrampt, 2001; Williams \& Losa, 2001; Tucker, 2002; Alçiçek et al., 2003; Giennenas et al., 2003). The reason for the lower performance in the $4 \%$ coriander than in the $2 \%$ coriander group could be due to a higher concentration of essential oil (Lee et al., 2004). In the present study ca. 400 $\mathrm{mg}$ essential oil $/ \mathrm{kg}$ diet were supplied when the $4 \%$ coriander seed was included in the diet, which might have been toxic to quails.

Unfortunately, reports on the value of coriander seed in poultry diets are limited. This study showed that the supplementation of $2 \%$ coriander seed in Japanese quail diets significantly improved body weight, feed conversion ratio and carcass yield over a growing period of six weeks. As a result, coriander seed may be used as a natural growth promoter in the place of antibiotics. This is apparently due to its appetizing effect in the diet, its stimulation of the digestive process and antimicrobial actions, which would contribute to a 
positive effect on performance. However, more evidence is needed to clarify whether aromatic plants can match the effects of antibiotics as feed additives in poultry diets.

\section{References}

Alçiçek, A., Bozkurt, M. \& Çabuk, M., 2003. The effect of essential oil combination derived from selected herbs growing wild in Turkey on broiler performance. S. Afr. J. Anim. Sci. 33, 89-94.

AOAC, 1990. Official Methods of Analysis Association of Agricultural Chemists, Virginia, D.C., U.S.A. pp. 746-780.

Ather, M.A.M., 2000. Polyherbal additive proves effective against vertical transmission of IBD. World Poultry-Elsevier 16, 50-52.

Basilico, M.Z. \& Basilico, J.C., 1999. Inhibitory effects of some spice essential oils on Aspergillus ochraceus 3174 growth and ocratoxin A production. Lett. Appl. Microbiol. 29, 238-241.

Bassett, R., 2000. Oreganos positive impact on poultry production. World Poultry-Elsevier 16, 31-34.

Chithra, V. \& Leelamma, S., 1997. Hypolipidemic effect of coriander seeds (Coriandrum sativum): mechanism of action. Plant Foods Hum. Nutr. 51, 167-72.

Chithra, V. \& Leelamma, S., 1999. Coriandrum sativum changes the levels of lipid peroxides and activity of antioxidant enzymes in experimental animals. Ind. J. Biochem. Biophys. 36, 59-61.

Chithra, V. \& Leelamma, S., 2000. Coriandrum sativum--effect on lipid metabolism in 1,2-dimethyl hydrazine induced colon cancer. J. Ethnopharmacol. 71, 457-463.

Craig, W.J., 1999. Health-promoting properties of common herbs. Am. J. Clin. Nutr. 70 (Suppl.), 491-499.

Crampton, E.W. \& Maynard, L.A., 1983. The relation of cellulose and lignin content to nutritive value of animal feeds. J. Nutr. 15, 383-395.

Çabuk, M., Alçiçek, A., Bozkurt, M. \& İmre, N., 2003. Antimicrobial properties of the essential oils isolated from aromatic plants and using possibility as alternative feed additives. II. National Animal Nutrition Congress. 18-20 September, Konya, Turkey. pp.184-187.

Delaquis, P.J., Stanich, K., Girard, B. \& Mazza, G., 2002. Antimicrobial activity of individual and mixed fractions of dill, cilantro, coriander and eucalyptus essential oils. Int. J. Food Microbiol. 74, 101-109.

Elgayyar, M., Draughon, F.A., Golden, D.A. \& Mount, J.R., 2001. Antimicrobial activity of essential oils from plants against selected pathogenic and saprophytic microorganisms. J. Food Prot. 64,1019-1024.

Giannenas, I., Florou-Paneri, P., Papazahariadou, M., Christaki, E., Botsoglou, N.A. \& Spais, A.B., 2003. Effect of dietary supplementation with oregano essential oil on performance of broilers after experimental infection with Eimeria tenella. Arch. Tierernahr. 57, 99-106.

Gray, A.M. \& Flatt, P.R., 1999. Insulin-releasing and insulin-like activity of the traditional anti-diabetic plant Coriandrum sativum (Coriander). Br. J. Nutr. 81, 203-209.

Hernandez, F., Madrid, J., Garcia, V., Orengo, J. \& Megias, M.D., 2004. Influence of two plant extract on broiler performance, digestibility, and digestive organ size. Poult. Sci. 83, 169-174.

Hertrampt, J.W., 2001. Alternative antibacterial performance promoters. Poult. Int. 40, 50-52.

Hossein, H. \& Mohammad, M., 2000. Anticonvulsant effects of Coriandrum Sativum L. Seed extracts in mice. Arch. Irn. Med. 3, 182-184.

Jamroz, D. \& Kamel, C., 2002. Plant extracts enhance broiler performance. In non ruminant nutrition: Antimicrobial agents and plant extracts on immunity, health and performance. J. Anim. Sci. 80 (E. Suppl. 1), 41.

Langhout, P., 2000. New additives for broiler chickens. World Poultry-Elsevier 16, 22-27.

Lee, K.W., Everts, H. \& Beynen, A.C., 2004. Essential oils in broiler nutrition. Int. J. Poult. Sci. 3, 738-752.

Miura, K., Kikuzaki, H. \& Nakatani, N., 2002. Antioxidant activity of chemical components from sage (Salvia officinalis L.) and thyme (Thymus vulgaris L.) measured by the oil stability index method. J. Agric. Food Chem. 50, 1845-51.

NRC, 1994. Nutrient Requirements of Poultry. (9th rev.ed.). National Research Council. National Academy Press, Washington, D.C., USA.

Ramakrishna, R.R., Platel, K. \& Srinivasan, K., 2003. In vitro influence of species and spice-active principles on digestive enzymes of rat pancreas and small intestine. Nahrung 47, 408-412.

Schwarz, S., Kehrenberg, C. \& Walsh, T.R., 2001. Use of antimicrobial agents in veterinary medicine and food animal production. Int. J. Antimicro. Agents 17, 431-437. 
Singh, G., Kapoor, I.P., Pandey, S.K., Singh, U.K. \& Singh, R.K., 2002. Studies on essential oils: part 10; antibacterial activity of volatile oils of some spices. Phytother. Res. 16, 680-682.

SPSS, 1999. SPSS for Windows: Base System User's Guide, Release10.1, SPSS Inc., Chicago, USA.

Swanston-Flatt, S.K., Day, C., Bailey, C.J. \& Flatt, P.R., 1990. Traditional plant for diabetes. Studies in normal and streptozotocin diabetic mice. Diabetologia 33, 462-464.

Tucker, L., 2002. Botanical broilers: Plant extracts to maintain poultry performance. Feed Int. 23, 26-29.

Valero, M. \& Salmeron, M.C., 2003. Antibacterial activity of 11 essential oils against Bacillus cereus in tyndallized carrot broth. Int. J. Food Microbiol. 85, 73-81.

Wichtl, M., 1994. Herbal drugs and phytopharmaceuticals. CRC Press, Stuttgart. pp. 159-160.

Williams, P. \& Losa, R., 2001. The use of essential oils and their compounds in poultry nutrition. World Poultry-Elsevier 17, 14-15. 